Creative commons User License: CC BY-NC-ND

Abstracted by: EBSCOhost, Electronic Journals Service (EJS),

Google Scholar, Journal Seek, Scientific Commons,

Food and Agricultural Organization (FAO), CABI and Scopus
Journal of Agricultural Extension

Vol. 22 (2) June, 2018

ISSN(e): 24086851; ISSN(Print); 1119944X

http://journal.aesonnigeria.org

http://www.ajol.info/index.php/iae

Email: editorinchief@aesonnigeria.org

\title{
Service Quality of Public and Private Agricultural Extension Service Providers in Bangladesh
}

https://dx.doi.org/10.4314/jae.v22i2.13

\author{
Md. Mamun-ur-Rashid ${ }^{\star}$ \\ Department of Agricultural Extension \& Rural Development, Patuakhali Science and Technology \\ University, Room no: A/313, Dumki, Patuakhali -8602, Bangladesh. murashidpstu@gmail.com, \\ Cell: +8801712143236, Tel: +8804427-56014-508 (PABX),
}

\section{Qijie Gao}

College of Humanities and Development Studies, China Agricultural University, 2

Yuanmingyuan Xilu, Beijing, China. gaogi@cau.edu.cn Tel \& Fax: 86-10-6273-1492.

\section{Oliul Alam}

Upazila Agricultural Officer, Banaripara, Barisal, Bangladesh. oliulalam2@gmail.com Cell: $+8801728328086$

*corresponding author

\section{Abstract}

This paper examined service quality of multiple public and private agricultural extension service providers in Bangladesh. A total of 318 respondents from nine selected organizations were interviewed. The study also used key informant interviews, focus group discussions and informal interviews. Findings of the study revealed that all the selected organizations, irrespective of origin, had a significant negative difference between perceived and expected ratings, on all of the five service quality dimensions, namely tangibles, reliability, responsiveness, assurance, and reliability. The five selected dimensions of service quality accounted for 74.6 $\%$ of the variation in client satisfaction with the extension service in Bangladesh. Major issues hinder service quality were poor logistic support, scarcity of fund for doing true extension work, less use of information communication technology, lack of co-ordination among researchextension and extension service providers themselves, and political interference. A demand responsive extension service is obligatory for the survival of extension organizations in a changing context.

Key words: Service quality; SERVQUAL; Extension service; Multiple providers; Bangladesh.

\section{Introduction}

Agricultural extension service in Bangladesh does not work satisfactorily and many farmers hardly ever received agricultural extension service (Haq 2011; Porimol et al. 2008; Haq et al., 2004). Households have noticeably limited access to the agricultural 
Creative commons User License: CC BY-NC-ND

Abstracted by: EBSCOhost, Electronic Journals Service (EJS),

Google Scholar, Journal Seek, Scientific Commons,

Food and Agricultural Organization (FAO), CABI and Scopus
Journal of Agricultural Extension

Vol. 22 (2) June, 2018

ISSN(e): 24086851; ISSN(Print); 1119944X

http://journal.aesonnigeria.org

http://www.ajol.info/index.php/iae

Email: editorinchief@aesonnigeria.org

extension service of any kind (Bangladesh Integrated Agricultural Poverty Project, 2013). Uddin and Gao (2013) accused agricultural extension programmes of offering poor and back dated service.

Some of the many reasons for poor quality extension service in Bangladesh include an inappropriate policy capturing the changing scenario of agricultural extension, shortage of fund for doing true extension work, lack of proper logistic support for offering up to date and quick extension support, and scarcity of manpower and resources, etc. However, one of the important reasons that often remains invisible in the problem list might be measuring success of extension service based only on surplus production. In reality, measuring success of agricultural extension solely on the basis of increased production is problematic, as numerous other factors affect the performance of agriculture in some complex ways (Anderson and Feder, 2004). As a result, the former assumption of extension success related to increased adoption and hence increased production has gradually losing attention (Agbarevo and Benjamin, 2013; Christoplos, 1996). Nonetheless, this kind of measurement can make extension scapegoat in case of crisis spawn by other socio-political or economic factors.

In today's competitive environment, quality of service is considered as an essential strategy for success and survival. Service quality is important and strategic aspect in potential management of not only for public and private sector firms, but also non-profit making organizations (Rana et al., 2013). Nonetheless, measuring extension service quality form client perspectives can minimize the wastage of valuable resources and manpower by precise indication of programme strengths and weaknesses. However, in Bangladesh, little is known about the quality and performance of extension system from the client perspectives. So, measurement of extension service quality based on client opinion is enormously important for offering demand-driven extension service.

SERVQUAL is a standardized and reliable instrument that has been used by majority of work to date, endeavor to measure service quality (Rohini and Mahadevappa, 2006; Shahin, 2013; Lidhari, 2009), although there are a number of other models (Seth et al., 2005). Direct or modified application of the SERVQUAL model in measuring agricultural extension service organizations in no exception (Horri et al., 2012; Rana et al., 2013). Grīnberga-Zālīte (2011) in his study on the 'assurance of customer-guided training services' in Latvia found SERVQUAL model as an effective tool. Ruhana (2011) also applied SERVQUAL model for measuring quality of agricultural extension service in selected regency in Indonesia. Despite popularity, SERVQUAL has both theoretical and operational limitations, which have been underpinned by different theorists. Babakus and Boller (1992) argued that the number of service quality dimensions varies with particular service. Brown et al. (1993) explained that the measurement of scores of difference in expectation and perception of customers is often weak in reliability. Chatterjee and Chatterjee (2005) questioned appropriateness of the statistical analysis based on continuous responses as the responses are collected based on ordinal scale. 
Creative commons User License: CC BY-NC-ND

Abstracted by: EBSCOhost, Electronic Journals Service (EJS),

Google Scholar, Journal Seek, Scientific Commons,

Food and Agricultural Organization (FAO), CABI and Scopus
Journal of Agricultural Extension

Vol. 22 (2) June, 2018

ISSN(e): 24086851; ISSN(Print); 1119944X

http://journal.aesonnigeria.org

http://www.ajol.info/index.php/iae

Email: editorinchief@aesonnigeria.org

\section{Methodology}

This study was conducted in Mymensing district under Dhaka Division. Administratively Bangladesh is composed of four distinctive stages like divisions composed of districts, districts composed of Upazils, Upazilas are aggression of unions, and several villages constitute unions. To fulfill requirement of client and organizational diversity, this study also included Mithapukur and Pirgonj Upazila of Rangpur district and Purbadhola Upazila under Netrokona district. The selected Upazilas of Rangpur district are recognized for seed production, hence a good number of contract growers engaged in supplying seed to private companies are available here. Furthermore, the selected areas are appreciated for agricultural production and diversified farming, which attract a multitude of agricultural extension service providers.

All stakeholders within agricultural extension system comprise the population of this study. Primarily nine organizations three from each group of public (PUB), private profit (PPR) and private non-profit (PNP) sector had been purposefully selected to ensure inclusion of international, national and local organizations. Extension organizations funded and administered completely by the government were treated as PUB organization. PPR organizations are self-funded extension providers, offer service as a part of product promotion and/or maximizing profit. However, PNPs are donor supported autonomous and non-government organizations, provide free extension services to their clients for self-development. Following stratified random sampling method this study also selected 318 farmers from the three clusters of organizations, to ensure participation of male and female farmers from all categories of farms (Table 1). This study followed DAE's categorization of farmers land, such as Large ( $>3$ hectares), Medium (1.01-3 hectares), Small (0.201-1 hectare), Marginal (0.02-0.20 hectare), and Landless (Less than 0.02 hectare). First of all, an Upazila was randomly selected, then one/two union was selected from which few groups was selected based on gender and farm size. These groups constituted the population of the study. In all the cases, this study considered clients, who are active group member or contract grower of the concerned organization and receiving extension support for at least one year.

Table 1: Sampling frame of the study.

\begin{tabular}{llcc}
\hline $\begin{array}{l}\text { Type of } \\
\text { provider }\end{array}$ & \multicolumn{1}{c}{ Name of Service Provider } & \multicolumn{2}{c}{ Farmers } \\
\cline { 2 - 4 } & & Pop. & Sample \\
& DUB & Department of Agricultural Extension (DAE) & 30 \\
& Department of Youth Development (DYD) & 97 & 35 \\
& Bangladesh Agricultural Development Corporation (BADC) & 90 & 32 \\
\hline PNP & CARE-Bangladesh & 90 & 39 \\
& Bangladesh Agricultural University Extension Center (BAUEC) & 82 & 32 \\
& Sabolambi Unnayan Sanghstha & 96 & 34 \\
\hline PPR & Lalteer Seed Company Limited & 98 & 40 \\
& Metal Agro Limited & 85 & 33 \\
& Supreme Seed Company Limited & 90 & 35 \\
\hline Total & & 828 & 318 \\
\hline
\end{tabular}


Creative commons User License: CC BY-NC-ND

Abstracted by: EBSCOhost, Electronic Journals Service (EJS), Google Scholar, Journal Seek, Scientific Commons,

Food and Agricultural Organization (FAO), CABI and Scopus
Journal of Agricultural Extension

Vol. 22 (2) June, 2018

ISSN(e): 24086851; ISSN(Print); 1119944X

http://journal.aesonnigeria.org

http://www.ajol.info/index.php/iae

Email: editorinchief@aesonnigeria.org

This research was mainly based on quantitative approach. However, to explore causes of low service quality, this study also used qualitative methods like key informant interviews, focus group discussions, informal interviews, and consult related published documents. Quantitative methods such as descriptive statistics, gap analysis, Z test and Ordinary Least Square (OLS) regression were used to analyze data. All statistical procedures, except $Z$ test were accomplished using SPSS 11.5.

A structured questionnaire was used to collect quantitative information. An arithmetic mean value for each of the dimensions of SERVQUAL based on perception and expectation were obtained. The differences between mean values reveal SERVQUAL evaluation.

Service quality $(S Q)=$ Customer's perception $(P)$ - Customer's expectations $(E)$ In equation form, it can be expressed as follows:

Where,

$$
S Q_{i}=\sum_{j=1}^{k}\left(P_{i j}-E_{i j}\right)
$$

$S Q_{i}=$ Perceived service quality of individual ' 1 ';

$\mathrm{K}=$ Number of service attributes/items;

$\mathrm{P}=$ Perception of individual ' $I$ ' with respect to performance of service organization's attribute ' $\mathrm{j}$ ';

$\mathrm{E}=$ Service quality expectation of attribute ' $\mathrm{j}$ ' that is relevant norm for individual ' $\mathrm{l}$ '.

(Parasuraman et al., 1988)

In order to determine the reliability of used instrument Cronbach's alpha analysis was performed. For all of the five selected dimensions, Alpha values were ranged from 0.79 to 0.81 , which are more than the value 0.70 suggested by Nunnally (1978), hence indicating an acceptable level of reliability.

\section{Results and Discussion}

\section{Demographic Profile of the Respondents}

The total number of clients interviewed in this research was 318 (269 male and 49 female). Mean age of the farmer respondents was $40.65(S D=12.66)$. The majority of the respondents (35.53\%) achieved secondary level education while almost half of the respondents were either illiterate $(20.75 \%)$ or had primary level education $(24.84 \%)$. Average per capita annual income equals to 185.30 thousand Taka $(S D=348$. 62). In terms of farm size, little less than half $(44.33 \%)$ of the respondents were marginal while $23.89 \%$ were small farmers and $21.38 \%$ medium farmers. 
Creative commons User License: CC BY-NC-ND

Abstracted by: EBSCOhost, Electronic Journals Service (EJS),

Google Scholar, Journal Seek, Scientific Commons,

Food and Agricultural Organization (FAO), CABI and Scopus
Journal of Agricultural Extension

Vol. 22 (2) June, 2018

ISSN(e): 24086851; ISSN(Print); 1119944X

http://journal.aesonnigeria.org

http://www.ajol.info/index.php/iae

Email: editorinchief@aesonnigeria.org

\section{Gap Between Perceived and Expected Extension Service}

Rating of perceived and expected scores, as represented in Table 2, public organizations have maximum gap $(-1.68)$ in responsiveness dimension followed by reliability (mean gap $=-1.36$ ) and empathy (mean gap $=-1.16)$. However, the minimum gap was observed in assurance and tangible dimensions, which equals to -0.94 and -0.97 respectively. Findings related to PPR organizations connote that responsiveness dimensions had largest service gaps (mean difference $=-1.70$ ). Based on the difference between perceived and expected scores other dimensions were reliability (mean gap= -1.64 ), empathy (mean gap $=-1.59$ ), assurance (mean gap $=-1.55$ ) and tangibles (mean gap $=-$ 1.41).

Table 2: Gap analysis result of perceived and expected score for different service providers.

\begin{tabular}{|c|c|c|c|c|c|c|c|}
\hline \multirow{2}{*}{$\begin{array}{l}\text { Org. } \\
\text { Type }\end{array}$} & \multirow{2}{*}{$\begin{array}{l}\text { Service quality } \\
\text { dimension (SQD) }\end{array}$} & \multicolumn{2}{|c|}{ Perceptions } & \multicolumn{2}{|c|}{ Expectations } & \multirow{2}{*}{$\begin{array}{c}\text { Mean } \\
\text { gap } \\
\text { (P-E) }\end{array}$} & \multirow[t]{2}{*}{$\mathbf{Z}$} \\
\hline & & Mean & SD & Mean & SD & & \\
\hline \multirow{5}{*}{ 号 } & Tangibles & 3.52 & 0.980 & 4.73 & 0.477 & -1.21 & $11.63^{*}$ \\
\hline & Reliability & 3.30 & 1.210 & 4.92 & 0.283 & -1.62 & $13.72^{*}$ \\
\hline & Responsiveness & 2.91 & 1.270 & 4.94 & 0.323 & -2.03 & $16.11^{*}$ \\
\hline & Assurance & 3.87 & 1.077 & 4.95 & 0.342 & -1.08 & $9.90^{*}$ \\
\hline & Empathy & 3.56 & 1.021 & 4.91 & 0.485 & -1.35 & $12.38^{*}$ \\
\hline \multirow{5}{*}{ 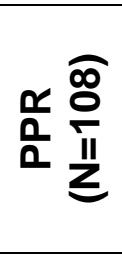 } & Tangibles & 3.39 & 1.170 & 4.95 & 0.247 & -1.56 & $13.68^{*}$ \\
\hline & Reliability & 3.17 & 1.270 & 4.96 & 0.216 & -1.79 & $14.67^{*}$ \\
\hline & Responsiveness & 3.09 & 1.205 & 4.97 & 0.182 & -1.88 & $16.49^{*}$ \\
\hline & Assurance & 3.31 & 1.230 & 4.95 & 0.240 & -1.64 & $13.89^{*}$ \\
\hline & Empathy & 3.28 & 1.215 & 4.95 & 0.241 & -1.67 & $14.15^{*}$ \\
\hline \multirow{5}{*}{ 음 $\frac{\widehat{y}}{\underline{z}}$} & Tangibles & 3.97 & 0.737 & 4.90 & 0.280 & -0.93 & $10.33^{*}$ \\
\hline & Reliability & 3.90 & 0.902 & 4.93 & 0.258 & -1.03 & $11.44^{*}$ \\
\hline & Responsiveness & 3.63 & 0.920 & 4.94 & 0.250 & -1.31 & $14.55^{\star}$ \\
\hline & Assurance & 3.95 & 0.831 & 4.96 & 0.208 & -1.01 & $12.62^{*}$ \\
\hline & Empathy & 4.10 & 0.817 & 4.95 & 0.256 & -0.85 & $10.24^{*}$ \\
\hline
\end{tabular}

${ }^{*} \mathrm{P} \leq 0.05$

Table 2, shows that the highest service gap for PNP organizations was observed in responsiveness dimensions (mean gap $=-1.19)$ followed by reliability (mean gap $=-0.96)$ and assurance (man gap $=-0.92$ ). On the other hand, lowest gap was visible in tangible and empathy dimensions (respective mean service gap -0.85 and -0.83 ). Considering 60 respondents from each of public, private and NGO extension service in Chitradurga, Kolar, and Tumkur district of Karnataka State, India Sarvanan and Veeradhadraiah (2003), found almost similar result in line with our findings. The study noted that the 
Creative commons User License: CC BY-NC-ND

Abstracted by: EBSCOhost, Electronic Journals Service (EJS), Google Scholar, Journal Seek, Scientific Commons,

Food and Agricultural Organization (FAO), CABI and Scopus
Journal of Agricultural Extension

Vol. 22 (2) June, 2018

ISSN(e): 24086851; ISSN(Print); 1119944X

http://journal.aesonnigeria.org

http://www.ajol.info/index.php/iae

Email: editorinchief@aesonnigeria.org

performance of NGOs and Public extension service showed almost a similar status in terms of service quality while performance of Agribusiness-Firms were much lower, where $60 \%$ farmers rate service as low quality. In assessing performance of agricultural extension services rendered by the public sector and NGOs in the district Kohat of NWFP, Pakistan Ahmed et al. (2009), claimed that farmers were satisfied with the working efficiency of NGOs regarding wheat, maize, etc., compared to public service. However, a study in Andhra Pradesh, India showed disparity with our findings, where private (paid) providers offer better quality service compared to public services (Rana et al., 2013). In assessing the farmer's satisfaction of agronomic services in Ghana, using SERVQUAL model James et al. (2012), also found significant differences in all the dimensions suggested in SERVQUAL model. However, their study found a maximum gap in reliability dimension (-1.06) while the least gap was observed in tangible dimension $(-0.63)$. The maximum difference between perception and expectation was noted in Responsiveness aspect.

Table 3 shows that for PPR providers, clients feel that the office was not well equipped with up-to-date technologies, extension workers do not inform farmers about extension programs timely, do not maintain records of individual client, extension programs are less flexible to client's needs, and extension workers do not keep. 
Creative commons User License: CC BY-NC-ND

Abstracted by: EBSCOhost, Electronic Journals Service (EJS), Google Scholar, Journal Seek, Scientific Commons,

Food and Agricultural Organization (FAO), CABI and Scopus
Journal of Agricultural Extension

Vol. 22 (2) June, 2018

ISSN(e): 24086851; ISSN(Print); 1119944X

http://journal.aesonnigeria.org

http://www.ajol.info/index.php/iae

Email: editorinchief@aesonnigeria.org

Table 3: Top ten criteria with highest service gap for PUB $(n=106)$, PPR $(n=108)$ and PNP ( $n=104)$, organizations.

\begin{tabular}{|c|c|c|c|c|c|c|c|}
\hline \multicolumn{2}{|r|}{ Criteria } & \multicolumn{3}{|c|}{ B-A } & \multicolumn{3}{|c|}{ Rank } \\
\hline & & PUB & PPR & PNP & PUB & PPR & PNP \\
\hline \multirow{2}{*}{ 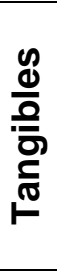 } & $\begin{array}{l}\text { The client service counter is well equipped } \\
\text { with up-to-date facilities. E.g. Telephone, } \\
\text { internet, etc. }\end{array}$ & & -2.48 & -1.05 & & 1 & 9 \\
\hline & $\begin{array}{l}\text { Material and information associated with the } \\
\text { extension service are visually appealing. } \\
\text { E.g. Leaflet, poster, etc. }\end{array}$ & -1.70 & & & 7 & & \\
\hline \multirow{3}{*}{ 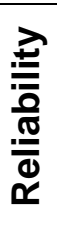 } & Extension service provider is dependable. & -1.64 & & & 8 & & \\
\hline & $\begin{array}{l}\text { Extension worker supply promised materials } \\
\text { (document, input) in time. }\end{array}$ & -1.79 & -1.99 & -1.08 & 6 & 5 & 6.5 \\
\hline & $\begin{array}{l}\text { Extension worker keeps record of farmers } \\
\text { accurately. }\end{array}$ & -1.88 & -2.08 & -1.04 & 3 & 3 & 10 \\
\hline \multirow{4}{*}{ 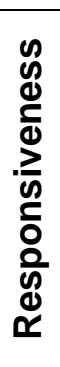 } & $\begin{array}{l}\text { Extension staffs timely inform farmers about } \\
\text { extension activities. }\end{array}$ & -1.44 & -1.74 & & 9 & 8.5 & \\
\hline & $\begin{array}{l}\text { Service provider staffs always willing to help } \\
\text { farmers. }\end{array}$ & -1.85 & & -1.24 & 4 & & 3 \\
\hline & $\begin{array}{l}\text { Extension Services are flexible to client } \\
\text { wishes. }\end{array}$ & -2.48 & -2.19 & -1.56 & 1 & 2 & 1 \\
\hline & $\begin{array}{l}\text { I receive prompt service from service } \\
\text { provider staff. }\end{array}$ & -2.32 & -2.00 & -1.51 & 2 & 4 & 2 \\
\hline \multirow{3}{*}{ 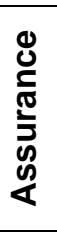 } & The service provider is credible. & & -1.74 & & & 8.5 & \\
\hline & $\begin{array}{l}\text { I feel safe conducting business with service } \\
\text { provider staff. }\end{array}$ & & -1.78 & -1.08 & & 6 & 6.5 \\
\hline & $\begin{array}{l}\text { Service staffs seem to receive adequate } \\
\text { support form service provider to do their job. }\end{array}$ & & & -1.06 & & & 8 \\
\hline \multirow{4}{*}{ 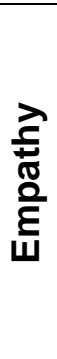 } & $\begin{array}{l}\text { The timing of the extension program is } \\
\text { comfortable for all clients. }\end{array}$ & & -1.69 & & & 10 & \\
\hline & $\begin{array}{l}\text { The service provider gives special attention } \\
\text { to each client. }\end{array}$ & -1.42 & & -1.14 & 10 & & 5 \\
\hline & $\begin{array}{l}\text { Extension worker is interested in satisfying } \\
\text { customer's need. }\end{array}$ & -1.80 & & -1.21 & 5 & & 4 \\
\hline & $\begin{array}{l}\text { Place location of extension program is } \\
\text { convenient for all clients. }\end{array}$ & & -1.76 & & & 7 & \\
\hline
\end{tabular}

earlier promise. Top ten criteria for PNP providers with highest service gap represents that clients' expectations noticeably fall short in case of flexibility of extension program according to clients wishes, getting rapid service, extension worker's willingness to help farmers, and interest of extension worker in satisfying farmers' needs. Tabulation of top ten criteria with highest service gap for PUB organizations revealed that extension workers do not inform farmers about extension activities on time. Nonetheless, the 
Creative commons User License: CC BY-NC-ND

Abstracted by: EBSCOhost, Electronic Journals Service (EJS),

Google Scholar, Journal Seek, Scientific Commons,

Food and Agricultural Organization (FAO), CABI and Scopus
Journal of Agricultural Extension

Vol. 22 (2) June, 2018

ISSN(e): 24086851; ISSN(Print); 1119944X

http://journal.aesonnigeria.org

http://www.ajol.info/index.php/iae

Email: editorinchief@aesonnigeria.org

extension service providers also lack in offering rapid service, willingness to help farmers, keeping individual farmer records and interest in satisfying farmer needs.

\section{Effect of Service Quality Dimensions on Customer Satisfaction}

The regression results in Table 4 mirrored that five perceived service quality dimensions explained $74.6 \%$ of customer satisfaction with the agricultural extension service in Bangladesh $\left(F_{5,312}=397.74, P \leq 0.000\right)$, thereby confirming the fit of the model. This finding confirmed that service quality dimensions are strong predictors of client satisfaction. However, it is noteworthy to mention that SERVQUAL dimensions can't explain $25.4 \%$ of the farmer's overall satisfaction with extension services they receive from different extension service providers. Values in Table 4 indicate that perceived responsiveness have the strongest effect on customer satisfaction $(\beta=0.298, P \leq 0.01)$. Perceived assurance $(\beta=0.236, P \leq 0.01)$ and perceived reliability $(\beta=0.139, P \leq 0.05)$ had almost similar amount of effect on client satisfaction with extension service, whereas perceived tangibles $(\beta=0.093, P \leq 0.05)$ has a comparatively less effect on

Table 4: Regression results of quality dimensions and client satisfaction.

\begin{tabular}{llllr}
\hline Predictor Variable & B & SE & Beta & t-value \\
\hline Tangibles perceived & 0.212 & 0.099 & 0.093 & $2.13^{*}$ \\
Reliability perceived & 0.252 & 0.113 & 0.139 & $2.23^{*}$ \\
Responsiveness perceived & 0.538 & 0.103 & 0.298 & $5.22^{*}$ \\
Assurance perceived & 0.463 & 0.116 & 0.236 & $3.97^{*}$ \\
Empathy perceived & 0.275 & 0.111 & 0.139 & $2.47^{*}$ \\
\hline
\end{tabular}

${ }^{*} \mathrm{P} \leq 0.05$

customer satisfaction followed by perceived empathy $(\beta=0.136, P \leq 0.05)$. All the five dimensions of service quality played pivotal role, in increasing client satisfaction with extension service, hence all extension service providers should pay special attention on improving SERVQUAL dimensions. James et al. (2012), in their study in Ghana, also found similar findings in measuring service quality of agronomic service with the application of SERVQUAL model. Similarly, Loke et al. (2011) and Randheer et al. (2011) in their studies found a significant positive relationship between service quality and client satisfaction except the dimension tangibles or physical facilities.

As argued by Pariseau and McDaniel (1997), if there is an agreement that service quality exceeds, meets or falls short of expectations, there would be a common premise for continuation on improvement of the service quality level. This study confirmed that PUB, PPR and PNP organizations did not provide expected level of service for their clients. Client expectations noticeably fall short of their expectation in terms of all dimensions proposed in SERVQUAL model. The biggest differences in expectation and perception were observed in responsiveness and reliability dimensions. Since responsiveness and reliability encompass willingness to help farmers, rapid service delivery, dependability and 
Creative commons User License: CC BY-NC-ND

Abstracted by: EBSCOhost, Electronic Journals Service (EJS),

Google Scholar, Journal Seek, Scientific Commons,

Food and Agricultural Organization (FAO), CABI and Scopus
Journal of Agricultural Extension

Vol. 22 (2) June, 2018

ISSN(e): 24086851; ISSN(Print); 1119944X

http://journal.aesonnigeria.org

http://www.ajol.info/index.php/iae

Email: editorinchief@aesonnigeria.org

accuracy or service, such findings represented that extension organizations are lacking in willingness to help farmers, promptness in offering service, dependability and accuracy of extension service.

Service gap score mirrored that maximum service gap exists in case of PPR organizations followed by the PUB and PNP organization. NGOs have a number of advantages over other extension providers. The majority of NGOs are smaller and horizontally structured with short lines of communication, which facilitate rapid responding flexibility and rapidly to clients' needs. Funds may be available and easier to acquire for transport and other operational cost. Bureaucracy is limited; services are well managed, more flexible in their programs than state extension system due to their size and philosophy. Nonetheless, except few large NGOs most of the NGOs are highly localized, having limited geographical coverage and deal with a limited number of clients which might help them manage quality extension service. Virtually, all kinds of farmers throughout the country are clients of public extension service. So, it is highly difficult to offer quality service with poor management, inadequate financial capacity, human resources, and other facilities. However, perceived scores confirmed that all of these providers are playing remarkable role in providing extension service, although there is a noticeable difference of gaps existed among the service providers.

This study revealed that service quality dimensions can contribute to $74.6 \%$ variation of client satisfaction. This is a confirmation that the SERVQUAL model can be effectively used for measuring service quality in agricultural extension service. It is also important to note that several other studies also revealed that SERVQUAL can precisely assess quality of agricultural extension service. However, further research considering a different type of service and population is essential, as evidences of application of the SERVQUAL model in measuring agricultural extension service are still very limited compared to other service sectors.

\section{Causes of Poor Service Quality}

Causes of poor quality service were revealed by employing qualitative methods. Shortage of funds for doing true extension work is a major problem deteriorating quality of extension service. The Lion share of the budget for agricultural extension goes for salary and maintenance, hence minor proportion left for special extension programs like demonstration, training, etc. According to a panel of experts, $84 \%$ resources of DAE are spent for salaries while only $1.5 \%$ goes for field extension programs (Birner et al., 2010). A report of the World Bank (2005) also claimed that public extension system in Bangladesh is heavily suffering from a chronic shortage of sufficient fund to do its' day to day activities.

Scarce and unplanned training for extension workers-especially field level workers-also hinder service quality. No training needs assessment system is in practice for workers as 
Creative commons User License: CC BY-NC-ND

Abstracted by: EBSCOhost, Electronic Journals Service (EJS),

Google Scholar, Journal Seek, Scientific Commons,

Food and Agricultural Organization (FAO), CABI and Scopus
Journal of Agricultural Extension

Vol. 22 (2) June, 2018

ISSN(e): 24086851; ISSN(Print); 1119944X

http://journal.aesonnigeria.org

http://www.ajol.info/index.php/iae

Email: editorinchief@aesonnigeria.org

well as for farmers. According to a renowned professor of agricultural extension of the top agricultural university of Bangladesh,

'There is no training need assessment system in extension organizations for either demand-side and/or supply side participants; hence a remarkable amount of resources and valuable time is wasted.'

No/rare fundamental training on basics of extension, leadership, and group formation for extension staffs. In a focus group discussion, Sub-Assistant Agricultural Offers (SAAO)field level extension officers of DAE-claimed that they have remarkably less training compare to higher level officers, although they are the major provider of grass-root level extension service. The case is also similar for some non-government and private organizations, where field level extension workers received minimal training.

Less logistic support for field level extension workers, especially for public extension workers is a major problem. SAAOs in DAE receive a lump sum amount equal to 3 USD/month as their transportation cost and only a few extension workers have motorized vehicles. Interestingly, international NGOs having a high mobility capacity also provide nominal logistic support to their field workers. Nonetheless, the majority of the extension service providers don't have permanent offices at field level, hence farmers can't find extension workers in their crying need.

No reward and/or punishment for good or bad workers. Accountability to the client is almost zero, no matter whether the service providers are public, private or NGO. Lengthy and time consuming recruitment procedure, especially in public extension organizations influences service quality. Private profit and non-profit organizations don't want to recruit sufficient manpower for saving money, hence extension workers are overloaded with works, which affect service quality. For instance, in a group discussion, workers of an international NGO complained,

'We are hauled with different types of other works including agricultural extension, hence can't deposit sufficient time for extension service.'

A private company worker claimed that he has to cover a whole district as his working area. Insufficient salary and promotion creates frustrations, which in turn deteriorate service quality. The public extension workers are underpaid compared to private and nongovernment sector organizations. However, salaries of private and non-government organization staff were also less compared to other sector like bank, mobile companies, etc. In some cases, promotions for government works are very infrequent, which create frustration that affects service quality. For instance, an Upazila Youth Officer in Mymensingh district has been working in the same post from 1985.

Very limited use of ICT, particularly in public extension organizations, makes quality to compromise. This study found only one internet connection available in an Upazila office for 85 extension staffs. In his study, Swanson (2011) claimed that SAAOs seldom use their mobile phone for work, rather use it to respond incoming farmer questions as incoming calls are toll free. Although, SAAOs have their own mobile phone but most are 
Creative commons User License: CC BY-NC-ND

Abstracted by: EBSCOhost, Electronic Journals Service (EJS),

Google Scholar, Journal Seek, Scientific Commons,

Food and Agricultural Organization (FAO), CABI and Scopus
Journal of Agricultural Extension

Vol. 22 (2) June, 2018

ISSN(e): 24086851; ISSN(Print); 1119944X

http://journal.aesonnigeria.org

http://www.ajol.info/index.php/iae

Email: editorinchief@aesonnigeria.org

conventional mobile phone and capable only of voice call and SMS texting. Nonetheless, they don't get any amount as cell phone charge. Private and non-government organizations very often use mobile phone and internet for internal communication, but rarely use internet for helping farmers.

Maintenance of quality service is hampered due to lack of coordination among organizations. Extension providers do not maintain regular contact with different research institutions. Even coordination among public and private extension providers is often weak and confined to formal meetings only. Regional Coordinator of Alleviating Poverty in North East Bangladesh (APONE) Project in Mymensingh argued that,

'If there is no inbuilt mechanism for coordination in a project, the only coordination among NGO extension service providers are attending monthly meeting at Upazila and District level platforms.' Executive director of a Mymensing based local NGO reported,

'We have to nearly stop a very effective project of rabbit farming, due to lack of support from research organizations.'

Political interference in recruitment of staff and group formation creates problems. In group discussion, both public and private extension workers claimed that they have to negotiate local political leaders, for smooth running of extension programs. Deputy Director of a prominent government extension organization expressed, 'Local political leaders very often interfere in the selection of farmers for group formation. Sometimes, we have to recruit members who are not legible for that particular group. Even the ministers interfere if the group members have chances to get a substantial amount of loan.'

\section{Conclusion and Recommendations}

Farmer's perceptions remarkably fell short of expectations in all the five dimensions of service quality, hence confirmed the low quality of service for all kinds of service providers. Service providers showed a maximum gap in responsiveness and reliability dimension. PPR providers had the maximum service gap followed by PUB providers, whereas PNP providers showed a minimum service gap. Programme flexibility, offering rapid service, willingness to help clients, maintaining client records, and keeping the promise are some common areas of service improvement, need consideration for all kinds of service providers for enhancing service quality.

\section{References}

Agbarevo, M. N. (2013). Farmer's perception on effectiveness of agricultural extension delivery in Cross-River state Nigeria. IOSR Journal of Agriculture and Veterinary Science, 2(6): 1-7. 
Creative commons User License: CC BY-NC-ND

Abstracted by: EBSCOhost, Electronic Journals Service (EJS),

Google Scholar, Journal Seek, Scientific Commons,

Food and Agricultural Organization (FAO), CABI and Scopus
Journal of Agricultural Extension

Vol. 22 (2) June, 2018

ISSN(e): 24086851; ISSN(Print); 1119944X

http://journal.aesonnigeria.org

http://www.ajol.info/index.php/jae

Email: editorinchief@aesonnigeria.org

Ahmed, I., Idrees, M., Shah, N. and Shah, S. W. (2009). Performance digest of agricultural extension services rendered by public sector and NGOs in district of Kohat of NWFP, Pakistan. Sarhad Journal of Agriculture, 25(4): 617-621.

Anderson, J. R. and Feder, G.. 2004. Agricultural extension: good Intentions and hard realities. The World Bank Research Observer, 19(1): 41-60. doi: 10.1093/wbro/ikh013.

Babakus, E. and Boller, G. W. (1992). An empirical assessment of the SERVQUAL scale. Journal of Business Research, 24(3): 253-268.

Birner, R., Quisumbing, A. R. and Ahmed, N. (2010). Cross-cutting issues: governance and gender. Bangladesh Food Security Investment Forum, Dhaka, May 26-27.

Brown, T. J., Gilbart, A. Charchil, Jr. and Peter, J. P. (1993). Improving measurement of service quality. Journal of Retailing 11(1): 127-139.

Chatterjee, S. and Chatterjee, A. (2005). Prioritization of service quality parameter based on ordinal responses. Total Quality Management, 16(4): 477-489.

Christoplos, I. (1996). Poverty, Pluralism and Extension Practice. Gatekeeper Series No. 64, London: International Institute of Environment and Development.

Grīnberga-Zālīte, G. (2011). Assurance of customer-guided training services' quality at rural advisory centers. PhD diss., Latvia University of Agriculture.

Haq, A. Z. M., Taniguchi, K. and Ishida, A. (2004). The impact of farmer's education on income in Bangladesh. Journal of the Japanese Society of Agricultural Technology Management, 11(1): 13-21.

Haq, A. Z. M. (2011). Effect of extension contact on rice productivity in some selected sites of Gazipur district. Bangladesh Journal of Agricultural Research, 36(4): 723 732.

Horri, M. S., Nouri, I. Ehsanifar, M. and Hadavand, F. (2012). Customer satisfaction survey for government organizations (Case study: Markazi province agricultural Jihad organization). American Journal of Scientific Research, 54: 81-91.

Bangladesh Integrated Agricultural Poverty Project. (2014). Baseline household survey report. Development Impact Evaluation (DIME) \& Global Agriculture and Food Security Program, pp. 14 
Creative commons User License: CC BY-NC-ND

Abstracted by: EBSCOhost, Electronic Journals Service (EJS),

Google Scholar, Journal Seek, Scientific Commons,

Food and Agricultural Organization (FAO), CABI and Scopus
Journal of Agricultural Extension

Vol. 22 (2) June, 2018

ISSN(e): 24086851; ISSN(Print); 1119944X

http://journal.aesonnigeria.org

http://www.ajol.info/index.php/jae

Email: editorinchief@aesonnigeria.org

James, O. M., Emmanuel, O. D. and Robert, A. (2012). Assessing farmer's satisfaction of agronomic services received in Ghana using the SERVQUAL model - a case study of Kumasi Metropolis. International Journal of Business and Social Science, 3(19): 51-60.

Ladhari, R. A. (2009). Review of twenty years of SERVQUAL research. International Journal of Quality and Service Sciences, 1(2): 172-198.

Loke, A. P., Taiqo, A. A., Salim, H. M. and Downe, A. G. (2011). Service quality and customer satisfaction in a telecommunication service provider. International Conference on Financial Management and Economics, 11:24-29.

Nunnally, J. C. (1978). Psychometric Theory (2nd ed.). New York: McGraw-Hill.

Parasuraman, A., Zeithaml, V. A. and Berry, L. L. (1988). SERVQUAL: a multiple item scale for measuring consumer perceptions of service quality. Journal of Retailing, 64(1):12-40.

Pariseau, S. D., and McDaniel, J. R. (1997). Assessing service quality in school of business. International Journal of Quality and Reliability Management, 14(3): 204-218.

Porimol, P. (2008). Rice yield to leap on less irrigation reveals BADC Study. The Daily Star, Dhaka, 22 June, pp. 1.

Randheer, K., AL-Motawa, A. A. and Prince, V. J. (2011). Measuring commuters' perception on service quality using SERVQUAL in public transportation. International Journal of Marketing Studies, 3(1):1-14.

Rana, A. S., Reddy, G. P. and Sontakki, B. S. (2013). Perceived service quality of agricultural organizations comparative analysis of public and private sector. International Journal of Advances Research in Management and Social Sciences, 2(1): 286-295.

Rohini, R. and Mahadevappa, B. (2006). Service quality in Bangalore hospitals - an empirical study. Journal of Services Research, 6(1): 47-55.

Ruhana, F. (2010). Service quality measurement of agricultural extension in KPSDMPKP Regency of Garut. International Journal of Kybernology,1(2).

Saravanan, R. and Veerabhadraiah, V. (2003). Client satisfaction and their willingness to pay for public and private extension service. Tropical Agricultural Research, 
Creative commons User License: CC BY-NC-ND

Abstracted by: EBSCOhost, Electronic Journals Service (EJS), Google Scholar, Journal Seek, Scientific Commons,

Food and Agricultural Organization (FAO), CABI and Scopus
Journal of Agricultural Extension

Vol. 22 (2) June, 2018

ISSN(e): 24086851; ISSN(Print); 1119944X

http://journal.aesonnigeria.org

http://www.ajol.info/index.php/jae

Email: editorinchief@aesonnigeria.org

15: 87-97. Available at: http://www.saravananraj.net/wpcontent/uploads/2014/12/13 -Clientele-satisfaction R.-Saravanan.pdf

Shahin, A. (2013). SERVQUAL and model of service quality gaps: a framework for determining and prioritizing critical factors in delivering quality services. Available at: http://www.civilica.com/EnPaper-QUALITYMANAGEMENT04QUALITYMANAGEMENT04 024.html

Swanson, B. E. (2011). Assessment of Bangladesh's pluralistic extension system: a MEAS rapid scoping mission in Bangladesh. Modernizing Extension and Advisory Services (MEAS) Project, Report prepared for USAID, February.

Uddin, M. E. and Gao, Q. (2013). Prospects and challenges of agricultural extension service in Bangladesh. Asian Journal of Agriculture and Rural Development, 3(7): 477-487.

World Bank. (2005). Revitalizing the agricultural technology system in Bangladesh. Bangladesh Development Series, paper no. 7, Dhaka 